\title{
Spirocyclic thienopyrimidines: synthesis, new rearrangement under Vilsmeier conditions and in silico prediction of anticancer activity
}

\author{
A. V. Kovtun ${ }^{1}$, S. V. Tokarieva ${ }^{1}$, S. A. Varenichenko ${ }^{1}$, O. K. Farat ${ }^{1}$, A. V. Mazepa ${ }^{2}$, \\ V. V. Dotsenko ${ }^{3,4}$, V. I. Markov ${ }^{1}$ \\ ${ }^{1}$ Ukrainian State University of Chemical Technology \\ 8, Gagarina Ave., Dnipro, Ukraine, 49005 \\ svetlanavarenichenko@gmail.com \\ ${ }^{2}$ A. V. Bogatsky Physico-Chemical Institute, National Academy of Sciences of Ukraine \\ 86, Lustdorfskaya Road, Odesa, Ukraine, 65080 \\ ${ }^{3}$ Kuban State University \\ 149 Stavropolskaya Str., Krasnodar, Russian Federation, 350040 \\ ${ }^{4}$ North Caucasus Federal University \\ 1a Pushkina Str., Stavropol, Russian Federation, 355017
}

\begin{abstract}
Aim. To find novel anticancer lead molecules among easily available spiro-fused thieno[2,3-d] pyrimidines. Methods. Organic synthesis, spectral methods and molecular docking. Results. New spiro heterocycles were synthesized by condensation of 2-aminothiophene-3-carbonitriles with cyclic ketones via Gevald reaction . Other model spirocyclic compounds were prepared by the reaction of 3-aminothieno[2,3-b]pyridine-2-carboxamides with cyclohexanone under acidic conditions. According to the docking studies against the EGFR ${ }^{\mathrm{WT}}$ the synthesized compounds revealed good binding energies ranging from -8.4 to $-10.2 \mathrm{kcal} / \mathrm{mol}$. The compounds were tested as inhibitors of protein kinase CK; 7', 8', 9',10'-tetrahydro-1' $H$-spiro[cyclohexane1,2'-pyrimido[4',5':4,5] thieno[2,3-b]quinolin]-4'(3' $H$ )-one showed the best binding energy while be bound by a hydrogen bond to Val66 amino acid residue. This compound also showed good results as a potential inhibitor of B-Raf kinase. Conclusion. New spiro-fused thieno[2,3d]pyrimidines have been synthesized. The inhibition activity of novel compounds as potential inhibitors of the EGFR, CK2, FGFR1 and B-raf kinases was examined. We found that spirofused thieno[2,3-d]pyrimidines undergo the rearrangement under Vilsmeier-Haack conditions to afford hitherto undescribed thienopyrimidines and-quinolines. The docking studies revealed that the rearranged products do not tend to form hydrogen bonds with the kinase amino acid residues and show moderate binding energies. Therefore, in contrast to the spiro-fused thieno[2,3-d]pyrimidines, the rearranged products cannot be considered as perspective targets for further screening.
\end{abstract}

K e y w o r d s: thieno[2,3-d]pyrimidines, thieno[2,3-b]pyridines, spiroheterocycles, VilsmeierHaack reaction, docking studies, anticancer activity, kinase inhibitors.

(C) 2020 A. V. Kovtun et al.; Published by the Institute of Molecular Biology and Genetics, NAS of Ukraine on behalf of Biopolymers and Cell. This is an Open Access article distributed under the terms of the Creative Commons Attribution License (http://creativecommons.org/licenses/by/4.0/), which permits unrestricted reuse, distribution, and reproduction in any medium, provided the original work is properly cited 


\section{Introduction}

Over the past few decades, the survival of cancer patients has improved significantly due to the progress in early detection and treatment [1].

The human genome encodes 538 kinases of proteins that transfer the $\gamma$-phosphate group with ATP to the residues of serine, threonine and tyrosine. Some of these kinases are responsible for signal transduction during many cellular processes including cell proliferation associated with human cancer. In recent years, the treatment of various types of cancer with low weight kinase inhibitors gained a success and became an effective in-clinic therapy. A survey of literature revealed some EGFR, CK2, FGFR1 and B-Raf protein kinase inhibitors to be useful as anti-cancer drugs.

Thus, first generation EGFR inhibitors are low weight tyrosine kinase inhibitors (TKI) such as erlotinib [2] and gefitinib [3], which bind to the adenosine triphosphatase (ATP) receptor site to inhibit the intracellular tyrosine kinase domain (TKD) of the receptor.

Casein kinase CK2 has been proven to play an important role in the pathogenesis of cancer [4].

FGFR 1 critically affects the development of cancer cells by enhancing point mutations or translocations. It has also been reported that an increase or activation of FGFR1 is associated with many types of cancer [5].

The activation of serine/threonine kinase B-Raf and, accordingly, of the mitogenic signal along the MAPK / ERK pathway leads to skin melanoma in most cases.

For wide range of human tumors, a constant relationship between increased severity and a decreased response to chemotherapy was ob- served in the case of oncogenic mutations of the B-Raf gene $[6,7]$.

Consequently, direct therapeutic inhibition of the oncogenic activity of B-Raf kinase provides a perspective for the treatment of these tumors. Because the majority of all melanomas contain an erroneous easily activated mutation (V600E) in the B-Raf oncogene [6], the targeted inhibition of the gene product of V599E is a reasonable therapeutic target in the treatment of the tumor.

Taking into account the role of the kinases in the development and progression of cancer diseases, we choose them as molecular targets for receptor-oriented screening in the series of thieno[2,3- $d]$ pyrimidines.

\section{Materials and Methods}

\section{Ligand and Receptor Structure Preparation}

Ligand structures were prepared using MGL Tools 1.5.6 software (MGL Tools 1.5.6 (Scrips Research Institute) http://mgltools.scripps.edu/) and Vega ZZ [8]. Receptor-based virtual screening was used to analyze the binding of the compound collection. Docking was performed at ATP-binding sites of protein kinases CK2 (database code RCSB 4GRB - 2.15 $\AA$ ), FGFR1 (database code RCSB 3GQI - 2.50 A), EGFR ${ }^{\mathrm{WT}}$ (database code PDB: $4 \mathrm{HJO}-2.75 \AA$ ), ${ }^{\mathrm{V} 599 \mathrm{E} B} \mathrm{~B}$ RAF(database code PDB: $1 \mathrm{UWJ}-3.5 \AA$ ) using Autodock 4.2.6. The structures taken for docking were kinase domains in an active state. Water molecules, ions and ligands were removed from the PDB file. The receptor structures were prepared using MGL Tools and 
AutoGrid. Hydrogen atoms were removed from nonpolar atoms. The incoming formats of receptor and ligands data were converted into PDBQT-format with Vega ZZ in AUTODOCK force field.

Flexible docking. Autodock 4.2.6 programs package was used for the receptor-based flexible docking [9].

\section{Visual analysis}

A visual analysis of the molecular docking results (interaction of compounds with the amino acid residues of CK2 and FGFR1 ATPbinding site) was carried out using Discovery Studio Visualizer 4.0 (http://accelrys.com/).

\section{Chemical synthesis}

${ }^{1} \mathrm{H}$ and ${ }^{13} \mathrm{C}$ NMR spectra were recorded on a Bruker Avance II 400 spectrometer (400 and $100 \mathrm{MHz}$, respectively) in DMSO- $d_{6}$ or DMSO- $d_{6}-\mathrm{CF}_{3} \mathrm{CO}_{2} \mathrm{D}$ (10:1) using TMS as an internal standard. Mass spectra (EI ionization, $70 \mathrm{eV}$ ) for compound 8 was recorded on a MX1321 apparatus with direct sample injection at $200{ }^{\circ} \mathrm{C}$ ionization chamber temperature $200{ }^{\circ} \mathrm{C}$. Mass spectra (FAB ionization) were registered on a VG-7070 spectrometer. Ion desorption from m-nitrobenzyl alcohol was done by a beam of argon atoms with an energy of $8 \mathrm{keV}$. Elemental analysis was performed on LECO CHN-900 Elemental analyzer. Melting points were determined on Electrothermal 9100 Digital apparatus. The reaction progress and purity of compounds were monitored by TLC on Silicagel gel 60 $\mathrm{F}_{254}$ (Merck) plates, eluent $\mathrm{CHCl}_{3}-i-\mathrm{PrOH}$ $(10: 1)$, visualization in the iodine chamber.

The starting 2-aminothiophene-3-carbonitriles $\mathbf{1}, \mathbf{2}$ were prepared by Gewald reaction starting from the corresponding cycloalkanone, sulfur and malononitrile [10]. 3-Amino5,6,7,8-tetrahydrothieno[2,3-b]quinoline2-carboxamide 4 [11], 3-amino-7,7-dimethyl5-oxo-5,6,7,8-tetrahydrothieno[2,3-b]quinoline-2-carboxamide 5 [12], and 3-amino-4,6dimethylthieno[2,3-b]pyridine-2-carboxamide 6 [13] were prepared by the known procedures.

Synthesis of spirocyclic compounds 3a-c: To the mixture of compound 1 or $\mathbf{2}(1 \mathrm{mmol})$ and the corresponding cyclic ketone $(1 \mathrm{mmol})$, in $\mathrm{EtOH}(5 \mathrm{~mL})$, a solution of $\mathrm{NaOH}(1 \mathrm{mmol})$ in $\mathrm{EtOH}(5 \mathrm{~mL})$ was added dropwise under stirring, and the reaction mixture was heated under reflux for $3 \mathrm{~h}$. The reaction mixture allowed cooling to room temperature. The resulting precipitate was collected by filtration. The crude products were recrystallized from $i$ $\mathrm{PrOH}$ to afford pure compounds 3a-c.

$5,6,7,8$-Tetrahydro- $1 H$-spiro [benzothieno[2,3- $d]$ pyrimidine-2,1'-cyclohexan]4(3H)-one (3a): Yield: 58 \%. M. p.: 208-210 ${ }^{\circ} \mathrm{C} .{ }^{1} \mathrm{H}$ NMR (400 MHz, DMSO- $d_{6}$ ), $\delta$, ppm: $7.32(1 \mathrm{H}, \mathrm{s}, \mathrm{NH}), 7.09(1 \mathrm{H}, \mathrm{s}, \mathrm{NH}), 2.63-2.65$ $\left(2 \mathrm{H}, \mathrm{m}, \mathrm{CH}_{2}-8^{\prime}\right), 2.43-2.45\left(2 \mathrm{H}, \mathrm{m}, \mathrm{CH}_{2}-5^{\prime}\right)$, $1.50-1.60\left(10 \mathrm{H}, \mathrm{m}, 5 \mathrm{CH}_{2}\right.$ spiro cycle $), 1.69-$ $1.80\left(4 \mathrm{H}, \mathrm{m}, 2 \mathrm{CH}_{2}-6,7\right) .{ }^{13} \mathrm{C} \mathrm{NMR}(100 \mathrm{MHz}$, DMSO- $\left.d_{6}\right), \delta$, ppm: $161.8(\mathrm{C}=\mathrm{O}), 155.4,131.6$, 117.9, 108.8, 70.2 (C-2), 36.1, 25.4, 24.7, 23.8, 23.0, 22.1, 20.9. MS (FAB), $m / z\left(I_{\text {отн }} \%\right): 277$ $[\mathrm{M}+\mathrm{H}]^{+}(90)$. Anal. calcd. for $\mathrm{C}_{15} \mathrm{H}_{20} \mathrm{~N}_{2} \mathrm{OS}: \mathrm{C}$, $65.18 ; \mathrm{H}, 7.29 ; \mathrm{N}, 10.14$. Found: C, 65.29; H, $7.15 ; \mathrm{N}, 10.26$

$5,6,7,8-T$ e t r a h y d r o - $1 H$ spiro[benzothieno $[2,3-d]$ pyrimidine-2,1'cyclopentan]-4(3H)-one (3b): Yield: $65 \%$. M. p.: $233-235{ }^{\circ} \mathrm{C} .{ }^{1} \mathrm{H}$ NMR $(400 \mathrm{MHz}$, DMSO- $\left.d_{6}\right), \delta$, ppm: $7.39(1 \mathrm{H}, \mathrm{s}, \mathrm{NH}), 7.32$ 
(1H, s, NH), 2.62-2.64 (2H, m, $\left.\mathrm{CH}_{2}-8^{\prime}\right), 2.45-$ $2.43\left(2 \mathrm{H}, \mathrm{m}, \mathrm{CH}_{2}-5^{\prime}\right), 1.58-1.62\left(8 \mathrm{H}, \mathrm{m}, 4 \mathrm{CH}_{2}\right.$ spiro cycle), $1.69-1.77\left(4 \mathrm{H}, \mathrm{m}, 2 \mathrm{CH}_{2}-6,7\right) .{ }^{13} \mathrm{C}$ NMR (100 MHz, DMSO- $d_{6}$ ), $\delta$, ppm: 162.3 $(\mathrm{C}=\mathrm{O}), 156.0,131.8,118.2,109.3,79.2(\mathrm{C}-2)$, 38.5, 25.5, 23.9, 23.1, 22.1, 21.9. MS (FAB), $m / z\left(I_{\text {отн }} \%\right): 263[\mathrm{M}+\mathrm{H}]^{+}(100)$. Anal. calcd. for $\mathrm{C}_{14} \mathrm{H}_{18} \mathrm{~N}_{2} \mathrm{OS}$ : C, 64.09; H, 6.91; N, 10.68. Found: C, 64.21; H, 6.79; N, 10.53.

3,5,6,7,8,9-Hexahydrospiro[cyclohep ta $[4,5]$ thieno $[2,3-d]$ pyrimidine-2, 1 'cyclohexan]-4(1H)-one (3c): Yield: $55 \%$. M. p.: 204-205 ${ }^{\circ} \mathrm{C} .{ }^{1} \mathrm{H}$ NMR $(400 \mathrm{MHz}$, DMSO- $\left.d_{6}\right), \delta$, ppm: $7.20(1 \mathrm{H}, \mathrm{s}, \mathrm{NH}), 7.16$ $(1 \mathrm{H}, \mathrm{s}, \mathrm{NH}), 3.00-2.98\left(2 \mathrm{H}, \mathrm{m}, \mathrm{CH}_{2}\right), 2.54-$ $2.52\left(2 \mathrm{H}, \mathrm{m}, \mathrm{CH}_{2}\right), 1.74-1.79\left(4 \mathrm{H}, \mathrm{m}, 2 \mathrm{CH}_{2}-\right.$ 6,7), $1.49-1.58\left(12 \mathrm{H}, \mathrm{m}, 6 \mathrm{CH}_{2}\right) .{ }^{13} \mathrm{C} \mathrm{NMR}(100$ MHz, DMSO- $\left.d_{6}\right), \delta$, ppm: $161.9(\mathrm{C}=\mathrm{O}), 153.8$, 136.9, 121.5, 109.9, 69.6 (C-2), 35.8, 31.9, 28.1, 27.6, 26.9, 26.8, 24.5, 20.8. MS (FAB), $\mathrm{m} / z\left(I_{\text {отн, }} \%\right): 291[\mathrm{M}+\mathrm{H}]^{+}(79)$. Anal. calcd. for $\mathrm{C}_{16} \mathrm{H}_{22} \mathrm{~N}_{2} \mathrm{OS}$ : C, 66.17; H, 7.64; N, 9.65. Found: C, 66.28; H, 7.50; N, 9.52.

Synthesis of spirocyclic compounds 7-9: A solution of the corresponding 3-aminothieno[2,3-b]pyridine-2-carboxamide 4-6 (1 mmol), cyclohexanone $(1 \mathrm{mmol})$ and catalytic amount of $p$-TsOH in $\mathrm{MeOH}$ (10-15 $\mathrm{ml}$ ) was heated under reflux for 2-3 $\mathrm{h}$. The reaction mixture was cooled to room temperature. The resulting precipitate was collected by filtration. The crude products were recrystallized from EtOH to afford pure compounds 7-9.

7', 8', 9', 1 0', Tet rahydro-1' $H$ spiro[cyclohexane-1,2'-pyrimido [4',5':4,5] thieno[2,3-b]quinolin]-4'(3'H)-one (7): Yield: $70 \%$. M. p.: $270-272{ }^{\circ} \mathrm{C} .{ }^{1} \mathrm{H}$ NMR $(400$ MHz, DMSO- $\left.d_{6}\right), \delta$, ppm: $8.17(1 \mathrm{H}, \mathrm{s}, \mathrm{CH}-$ pyridine cycle), $7.62(1 \mathrm{H}, \mathrm{s}, \mathrm{NH}), 7.21(1 \mathrm{H}, \mathrm{s}$, $\mathrm{NH}), 2.85-2.90\left(4 \mathrm{H}, \mathrm{m}, 2 \mathrm{CH}_{2}-7^{\prime}, 10^{\prime}\right)$, 1.76$1.85\left(10 \mathrm{H}, \mathrm{m}, 5 \mathrm{CH}_{2}\right.$ spiro cycle), $1.50-1.59$ (4H, m, $\left.2 \mathrm{CH}_{2}-8^{\prime}, 9^{\prime}\right) .{ }^{13} \mathrm{C} \mathrm{NMR}(100 \mathrm{MHz}$, DMSO- $\left.d_{6}\right), \delta$, ppm: $161.4(\mathrm{C}=\mathrm{O}), 158.5,158.2$, 143.1, 131.0, 128.2, 123.1, 101.3, 69.9 (C-2), 36.1, 32.4, 28.2, 24.7, 22.4, 22.2, 20.9. MS

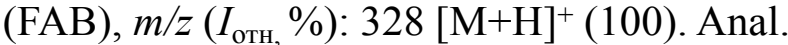
calcd. for $\mathrm{C}_{18} \mathrm{H}_{21} \mathrm{~N}_{3} \mathrm{OS}$ : C, 66.02; $\mathrm{H}, 6.46 ; \mathrm{N}$, 12.83. Found: C, 66.14; H, 6.35; N, 12.72.

8',8'-Dimethyl-8',9'-dihydro-1'Hspiro[cyclohexane-1,2'-pyrimido [4',5':4,5] thieno[2,3-b]quinoline]-4',10'(3'H,7'H)-dione (8): Yield: $75 \%$. M. p.: $312-315^{\circ} \mathrm{C} .{ }^{1} \mathrm{H}$ NMR (400 MHz, DMSO- $d_{6}$ ), $\delta$, ppm: 9.07 $(1 \mathrm{H}, \mathrm{s}, \mathrm{CH}$-pyridine cycle), $7.81(1 \mathrm{H}, \mathrm{s}, \mathrm{NH})$, $7.71(1 \mathrm{H}, \mathrm{s}, \mathrm{NH}), 3.06\left(2 \mathrm{H}, \mathrm{s}, \mathrm{CH}_{2}-9^{\prime}\right), 2.60$ $\left(2 \mathrm{H}, \mathrm{s}, \mathrm{CH}_{2}-7^{\prime}\right), 1.31-1.88\left(10 \mathrm{H}, \mathrm{m}, 5 \mathrm{CH}_{2}\right.$ spiro cycle), $6.13\left(6 \mathrm{H}, \mathrm{s}, 2 \mathrm{CH}_{3}\right) .{ }^{13} \mathrm{C} \mathrm{NMR}$ (100 MHz, DMSO- $d_{6}$ ), $\delta$, ppm: 196.9 (CO), $164.8,161.7(\mathrm{CONH}), 160.9,143.7,129.9$, 123.6, 123.3, 101.1, 70.1 (C-2), 51.1, 45.6, 35.9, 32.4, 27.5, 24.5, 20.6. MS (FAB), $m / z$ $\left(I_{\text {отн, }} \%\right): 370[\mathrm{M}+\mathrm{H}]^{+}(100)$. MS (EI), $m / z\left(I_{\text {отн, }}\right.$ $\%): 369[\mathrm{M}]^{+}$(55). Anal. calcd. for $\mathrm{C}_{20} \mathrm{H}_{23} \mathrm{~N}_{3} \mathrm{O}_{2} \mathrm{~S}$ : C, 65.01; H, 6.27; N, 11.37. Found: C, 65.13; H, 6.38; N, 11.24.

7',9'-Dimethyl-1'H-spiro[cyclohexane1,2 '-pyrimido $\left[3^{\prime}, 2^{\prime},: 4,5\right]$ thieno $[2,3-d]$ pyrimidine]-4'(3'H)-one (9): Yield: $78 \%$. M. p.: $271-273{ }^{\circ} \mathrm{C} .{ }^{1} \mathrm{H}$ NMR $(400 \mathrm{MHz}$, DMSO- $\left.d_{6}\right), \delta$, ppm: $7.81(1 \mathrm{H}, \mathrm{s}, \mathrm{NH}), 7.04$ $(1 \mathrm{H}, \mathrm{s}, \mathrm{NH}), 5.87$ (1H, s, CH-pyridine cycle), $2.70\left(3 \mathrm{H}, \mathrm{s}, \mathrm{CH}_{3}\right), 2.50\left(3 \mathrm{H}, \mathrm{s}, \mathrm{CH}_{3}\right.$, overlapped with DMSO signals), 2.02-2.04 $(2 \mathrm{H}$, $\left.\mathrm{m}, \mathrm{CH}_{2}\right), 1.50-1.54\left(8 \mathrm{H}, \mathrm{s}, 4 \mathrm{CH}_{2}\right)$. MS (FAB), $m / z\left(I_{\text {отн }}, \%\right): 302[\mathrm{M}+\mathrm{H}]^{+}(100)$. Anal. calcd. for $\mathrm{C}_{16} \mathrm{H}_{19} \mathrm{~N}_{3} \mathrm{OS}$ : C, 63.76; $\mathrm{H}, 6.35 ; \mathrm{N}, 13.94$. Found: C, 63.88; H, 6.20; N, 13.82. 
Synthesis of Vilsmeier-type rearranged products 10, 11. Methods A: The VilsmeierHaack reagent was prepared by mixing $\mathrm{POCl}_{3}$ ( $2 \mathrm{ml}, 22 \mathrm{mmol})$ and DMF (5 ml, $66 \mathrm{mmol})$ in an ice bath. The corresponding spiro compounds $3 \mathbf{a}$ or $8(7.2 \mathrm{mmol})$ were added to the prepared Vilsmeier reagent. The reaction mixture was heated in water bath at $80^{\circ} \mathrm{C}$ for $2 \mathrm{~h}$, then cooled to $10^{\circ} \mathrm{C}$, and treated with $15 \%$ aqueous $\mathrm{NaOH}(15 \mathrm{ml})$. The precipitate was filtered off, washed with $\mathrm{H}_{2} \mathrm{O}$, and resulted compounds were purified by recrystallization from $\mathrm{MeCN}$.

Method B: Compound 3a (2 g, $0.007 \mathrm{~mol})$ was mixed with DMF $(1 \mathrm{ml})$ and the slurry obtained was added portion wise to the cold Vilsmeier-Haack reagent prepared from DMF $(5 \mathrm{ml})$ and $\mathrm{POCl}_{3}(2 \mathrm{ml}, 0.022 \mathrm{~mol})$. The mixture was left to warm to room temperature for $0.5 \mathrm{~h}$ and maintained for 4 days at room temperature. Then it was poured onto ice and neutralized with $10 \% \mathrm{NaOH}$ solution to weakly basic reaction. The product was filtered off.

1 - C y clohe e - 1 - e n - 1 - y l - 5, 6, 7,8 tetrahydro[1]benzothieno[2,3- $d]$ pyrimidin4(1H)-one (10): Yield: $39 \%$ (method A and B). M. p.: $115-117{ }^{\circ} \mathrm{C}$ (petroleum ether). ${ }^{1} \mathrm{H}$ NMR (400 MHz, DMSO- $d_{6}$ ), $\delta$, ppm: 8.05 $(1 \mathrm{H}, \mathrm{s}, \mathrm{CH}-2), 5.84\left(1 \mathrm{H}, \mathrm{m}, \mathrm{CH}-2^{\prime}\right), 2.82-2.84$ $\left(4 \mathrm{H}, \mathrm{m}, 2 \mathrm{CH}_{2}\right), 2.70-2.72\left(4 \mathrm{H}, \mathrm{m}, 2 \mathrm{CH}_{2}\right), 2.17-$ $2.25\left(6 \mathrm{H}, \mathrm{m}, 3 \mathrm{CH}_{2}\right), 1.20-1.22\left(2 \mathrm{H}, \mathrm{m}, \mathrm{CH}_{2}\right)$. MS (FAB), $m / z\left(I_{\text {отн, }} \%\right): 287[\mathrm{M}+\mathrm{H}]^{+}(100)$. Anal. calcd. for $\mathrm{C}_{16} \mathrm{H}_{18} \mathrm{~N}_{2} \mathrm{OS}: \mathrm{C}, 67.10 ; \mathrm{H}$, 6.33; N, 9.78. Found: C, 67.23; H, 6.18; N, 9.68 .

1-Cyclohex-1-en-1-yl-8,8-dimethyl-8,9dihydropyrimido $\left[4^{\prime}, 5^{\prime}: 4,5\right]$ thieno $[2,3-b]$ quinoline-4,10(1H,7H)-dione (11): Yield: 40
\% (method B). M. p.: $213-215{ }^{\circ} \mathrm{C}(\mathrm{MeOH})$. ${ }^{1} \mathrm{H}$ NMR (400 MHz, DMSO- $d_{6}$ ), $\delta$, ppm: 8.80 (1H, s, CH-pyridine cycle), $8.47(1 \mathrm{H}, \mathrm{s}, \mathrm{CH}-2)$, $6.01\left(1 \mathrm{H}, \mathrm{m}, \mathrm{CH}-2^{\prime}\right), 3.16-3.18\left(2 \mathrm{H}, \mathrm{m}, \mathrm{CH}_{2}\right)$, 2.67-2.69 $\left(2 \mathrm{H}, \mathrm{m}, \mathrm{CH}_{2}\right), 2.23-2.36(4 \mathrm{H}, \mathrm{m}$, $\left.2 \mathrm{CH}_{2}\right), 1.65-1.77\left(4 \mathrm{H}, \mathrm{m}, 2 \mathrm{CH}_{2}\right), 1.08(6 \mathrm{H}, \mathrm{s}$, $\left.2 \mathrm{CH}_{3}\right)$. MS (FAB), $m / z\left(I_{\text {отн, }} \%\right): 380[\mathrm{M}+\mathrm{H}]^{+}$ (100). Anal. calcd. for $\mathrm{C}_{21} \mathrm{H}_{21} \mathrm{~N}_{3} \mathrm{O}_{2} \mathrm{~S}$ : C, 66.47; $\mathrm{H}, 5.58$; N, 11.07. Found: C, 66.33; H, 5.48; $\mathrm{N}, 11.19$.

$1,2,3,4,7,8,9,10-O$ ct a h y d r o [ 1$]$ benzothieno[2,3-b]quinolin-11-amine (12): A mixture of compound $3 \mathbf{a}(2.0 \mathrm{~g}, 0,013 \mathrm{mmol})$ and $\mathrm{POCl}_{3}(20 \mathrm{ml})$ was refluxed in absolute toluene $(70 \mathrm{ml})$ for $2 \mathrm{~h}$. The toluene was decanted off and the dark-brown, viscous residue was dissolved in $\mathrm{MeOH}$. Concentrated ammonia was added to adjust the mixture to alkaline reaction, and the product was extracted with $\mathrm{CH}_{2} \mathrm{Cl}_{2}(30 \mathrm{ml})$. The extract was dried over $\mathrm{Na}_{2} \mathrm{SO}_{4}$, and the solvent was evaporated. Yield: $45 \%$. M. p.: $192-194{ }^{\circ} \mathrm{C}$ (M. p.: $218^{\circ} \mathrm{C}$ [14]). ${ }^{1} \mathrm{H}$ NMR (400 MHz, DMSO- $\left.d_{6}\right), \delta$, ppm: $5.49\left(2 \mathrm{H}, \mathrm{s}, \mathrm{NH}_{2}\right), 2.97\left(2 \mathrm{H}, \mathrm{m}, \mathrm{CH}_{2}\right), 2.69-$ $2.70\left(4 \mathrm{H}, \mathrm{m}, 2 \mathrm{CH}_{2}\right), 2.43\left(2 \mathrm{H}, \mathrm{m}, \mathrm{CH}_{2}\right), 1.79$ $\left(8 \mathrm{H}, \mathrm{m}, 4 \mathrm{CH}_{2}\right)$. MS (FAB), $m / z\left(I_{\text {отн, }} \%\right): 259$ $[\mathrm{M}+\mathrm{H}]^{+}(100)$. Anal. calcd. for $\mathrm{C}_{15} \mathrm{H}_{18} \mathrm{~N}_{2} \mathrm{~S}: \mathrm{C}$, 69.73; H, 7.02; N, 10.84. Found: C, 69.51; H, $7.18 ; \mathrm{N}, 10.79$.

\section{Results and Discussion}

The synthesis, reactions and biological effects of isomeric thienopyrimidines have been reviewed extensively [15-24]. Thienopyrimidines have a great potential of application and were recognized as anticancer agents [25-30]. Earlier we have developed some original methods for the synthesis of functionalized thieno[2,3- $d]$ pyrimidines [31-33]. We 
also reported strong antimicrobial effects for some thieno[2,3-d]pyrimidin-4(3H)-(selen) ones [34]. The significant pharmacological potential of thienopyrimidines and a strong demand of new anticancer drugs prompted us to perform a receptor-based screening to find novel anticancer lead molecules among the easily available spiro-fused thieno[2,3- $d]$ pyrimidines.

With this aim, we synthesized spiro heterocycles 3a-c by condensation of Gewald's 2-aminothiophenes 1,2 with cyclic ketones (Scheme 1).
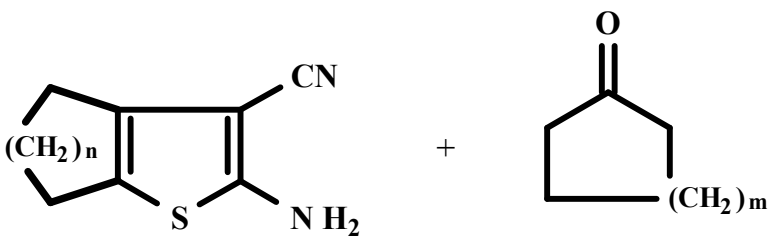

\section{1,2}

Scheme 1. Synthesis of spiro compounds 3a-c

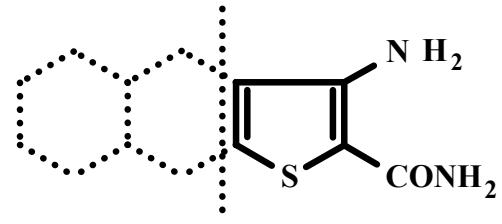

4-6
The model compounds 7-9 were prepared by condensation of 3-aminothieno[2,3-b]pyridine-2-carboxamides 4-6 with cyclohexanone under acidic conditions (Scheme 2). Noteworthy, thieno[2,3-b]pyridines as well as polycyclic ensembles bearing thienopyridine core also represent promising candidates for the anticancer screening [35-42].

For the receptor-oriented flexible screening, we used the Autodock 4 and the AutoDock Vina software packages [43, 44]. Additionally, the molecular modeling studies were performed in order to rationalize the anticancer activities
$\mathrm{NaOH}$

$\overrightarrow{\mathrm{EtOH}}$

O

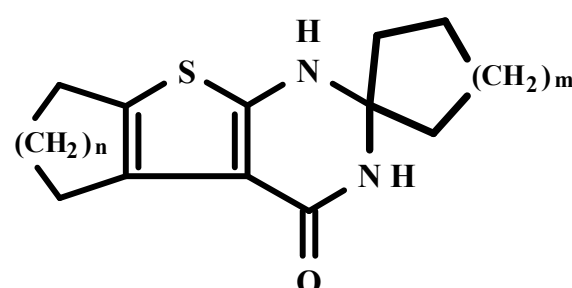

3a-c

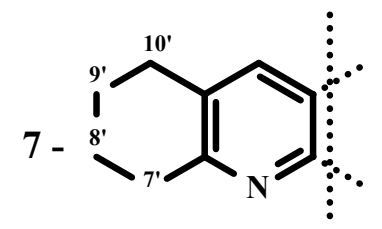<smiles>O=C1CCCCC1</smiles>

8 -

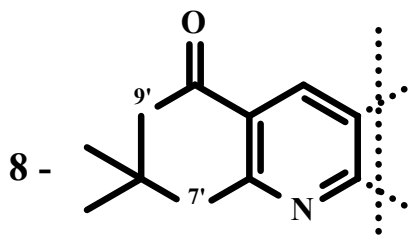

7-9<smiles>CC1=CC(C)=NC(C)(C)[C+]1(C)C</smiles>

Scheme 2. Synthesis of model compounds 7-9 
of the proposed compounds. All the synthesized thieno[2,3- $d]$ pyrimidine derivatives were subjected to the docking study together with the internal ligand, erlotinib, as a reference molecule to explore their calculated binding modes with the EGFR wild type receptor (EGFR ${ }^{\mathrm{WT}}$, PDB: 4HJO) [45]. The ATP binding pocket of EGFR ${ }^{\mathrm{WT}}$ consists of five main parts; sugar pocket, two hydrophobic regions, adenine binding pocket, and phosphate binding region.

The results of the docking studies against the EGFR ${ }^{W T}$ revealed that the synthesized compounds have similar orientations inside the ATP binding site. The designed compounds have good binding energies ranging from -8.4 to $-10.2 \mathrm{kcal} / \mathrm{mol}$ (Table 1 ).

As seen from Fig. 1, the oxygen atom of compound $\mathbf{8}$ forms a hydrogen bond with Lys721 amino acid residue with a distance of $2.30 \AA$.

The results of the compounds verification as inhibitors of protein kinase CK2 are presented in the Table 2. Among the studied compounds, compound 7 revealed hydrogen bonding interaction with Val66 amino acid residue and showed the best binding energy value (Fig. 2).

All spiro compounds showed the interaction with Val66 and Ile174 key amino acid residues for CK2 to form a $\pi-\sigma$ and $\pi$-alkyl contacts, respectively. Noteworthy, such contacts are necessary for selective inhibition of protein kinase CK2 [46]. The compounds 7 and 9 were joined via hydrophobic interactions at the CK2 ATP-acceptor site with the amino acid residues Val53, Val66, Met1163, Ile174 and by a hydrogen bond with Val116 $(2.67 \AA)$, which was located in the hinge re- gion of the kinase. There was a $\pi$-Sulfur link between the thiophene cycle and the amino acid residue Met163.

When the FGFR1 kinase inhibitors were tested, none of the studied compounds formed any hydrogen bonds with the ATP-acceptor site FGFR1. The binding energies against FGFR1 are presented in Table 3.

The previous generations of B-Raf inhibitors showed Raf inhibitory activity at the concentrations as low as nanomolar. However, the therapeutic effects of such inhibitors were complicated by the lack of bioavailability and a number of non-specific targets that are also affected inhibition [47]. Noteworthy, thienopyrimidine ligands have not yet been studied as inhibitors of B-Raf kinase. The binding energies are given in the Table 4.

In addition to the various visible van der Waals interactions with B-RAF inhibitors, the hydrogen bonds with the active sites of the protein Glu500 and Cys531 also contributed to the binding of a ligand. Thus, a carbonyl oxygen atom of the compound 7 increased the affinity compared to the carbon atom and formed a hydrogen bond with the main nitrogen atom of the Cys531 residue in the region of the interdomain hinge. Compounds $\mathbf{7}$ and $\mathbf{8}$ were found to form a $\pi-\pi$ interaction between their thiophene rings and benzene ring of Phe594 (Fig 3).

In continuation of our studies of biologically active thienopyrimidines, we investigated the reaction of spiro heterocycles $\mathbf{3 a}$ and 7 with the Vilsmeier -Haack reagent. In our previous papers we reported the original rearrangement of spiro- fused pyrimidines and 1,3-benzoxazines into acridines and benzoxanthenes, respectively [48-51]. 
A. V. Kovtun, S. V. Tokarieva, S. A. Varenichenko et al.

Table 1. The docking binding free energies of the synthesized compounds 3a-c,7-9 against EGFR'

\begin{tabular}{c|c|c|c|c|c|c}
\hline Compound & $3 \mathrm{a}$ & $3 \mathrm{~b}$ & $3 \mathrm{c}$ & 7 & 8 & 9 \\
\hline Binding free energy $(\mathrm{kcal} / \mathrm{mol})$ & -9.3 & -8.7 & -9.5 & -9.2 & -10.2 & -8.4 \\
\hline
\end{tabular}
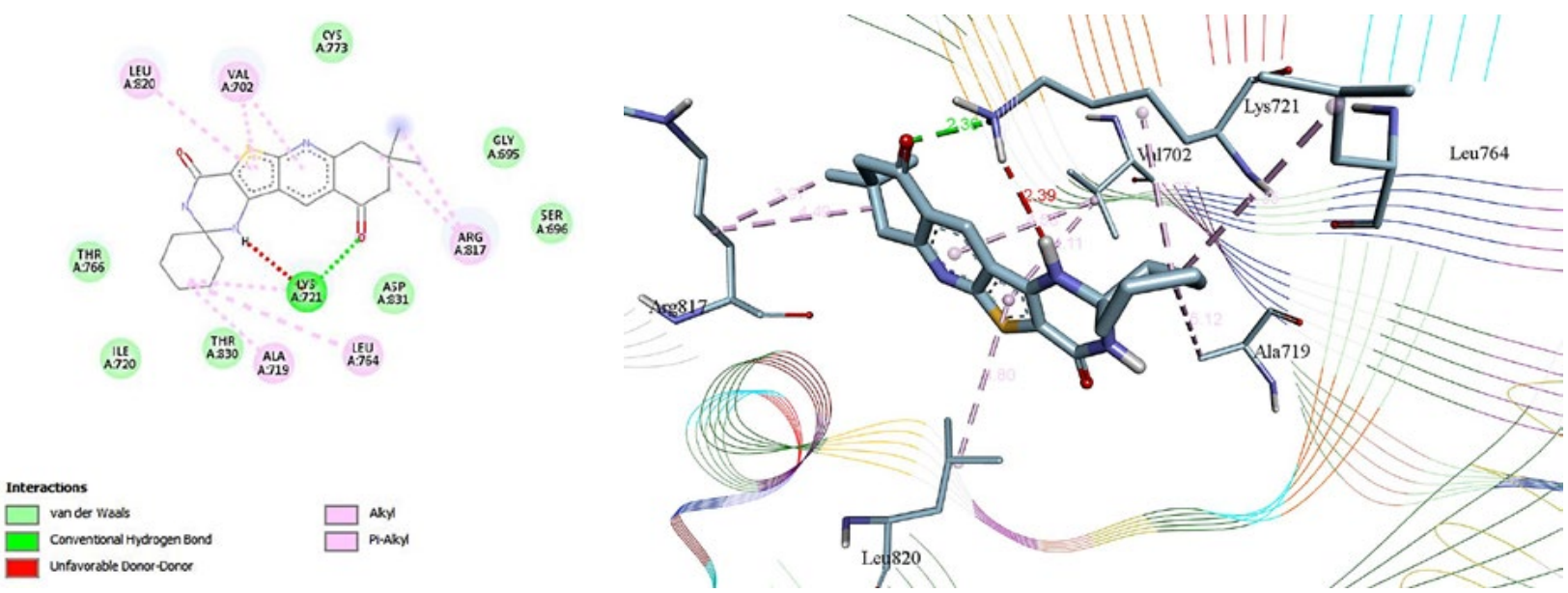

Fig. 1. Binding model of compound 8 for the best docked pose in the ATP-binding site of receptor EGFR (model of the complex obtained by molecular docking, hydrogen bonds are shown in green dashed lines).

Table 2. The docking binding free energies of the synthesized compounds 3a-c,7-9 against CK2

\begin{tabular}{c|c|c|c|c|c|c}
\hline Compound & $3 \mathrm{a}$ & $3 \mathrm{~b}$ & $3 \mathrm{c}$ & 7 & 8 & 9 \\
\hline Binding free energy $(\mathrm{kcal} / \mathrm{mol})$ & -9.3 & -8.8 & -9.6 & -10.0 & -9.5 & -9.4 \\
\hline
\end{tabular}

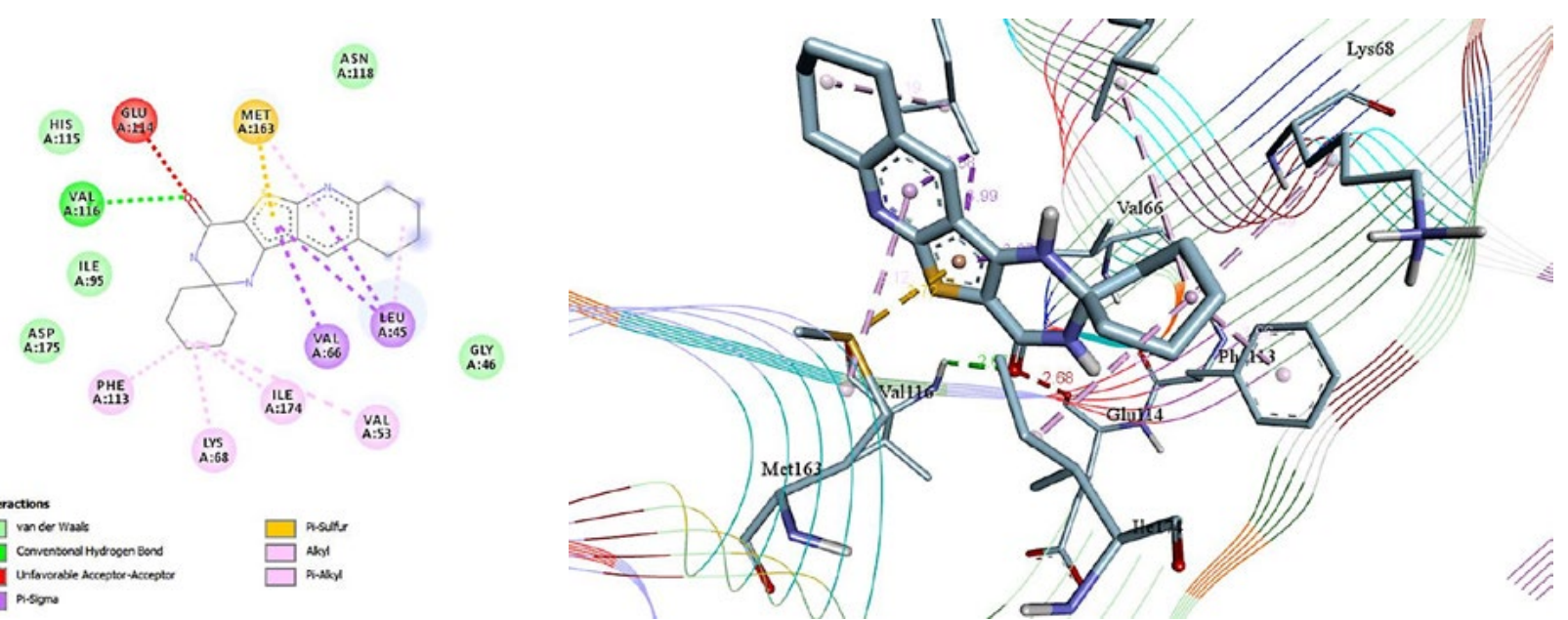

Fig. 2. Binding model of compound 7 for the best docked pose in the ATP-binding site of receptor CK2 (model of the complex obtained by molecular docking, hydrogen bonds are shown in green dashed lines). 


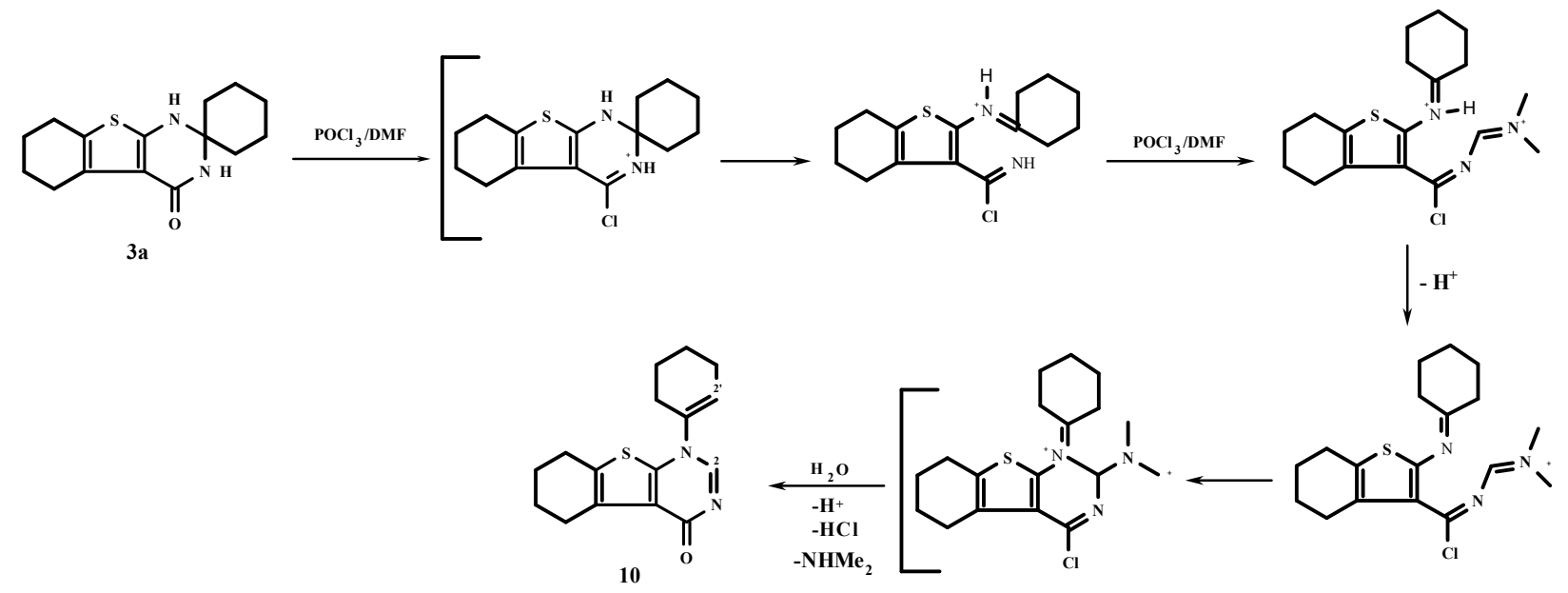

Scheme 3. The plausible mechanism for the formation of compound $\mathbf{1 0}$<smiles>CC1(C)CC(=O)c2cc3c(nc2C1)sc1c(=O)ncn(C2=CCCCC2)c13</smiles>

7

11<smiles>Nc1c2c(nc3sc4c(c13)CCCC4)CCCC2</smiles>

12
Scheme 4. Synthesis of 1-cyclohex-1-en-1-yl-8,8dimethyl-8,9-dihydropyri m i d o [ 4', 5': 4,5 ] thieno[2,3-b]quinoline4,10(1H,7H)-dione 11<smiles>O=C1NC2(CCCCC2)Nc2sc3c(c21)CCCC3</smiles>

$3 \mathbf{a}$
Scheme 5. Synthesis of thieno[2,3-b]quinoline $\mathbf{1 2}$
We found that treatment of spiro thienopyrimidine 3a with an excess of Vilsmeier-Haack reagent for 4 days at room temperature afforded 1-cyclohex-1-en-1-yl-5,6,7,8-tetrahydro[1] benzothieno[2,3-d]pyrimidin-4(1H)one $\mathbf{1 0}$ in a moderate yield. The same rear- rangement product was isolated when the reagents were heated at $100-110^{\circ} \mathrm{C}$ for $3 \mathrm{~h}$ (Scheme 3).

Compound 7 reacted in a similar manner to give the rearranged product $\mathbf{1 1}$ in $40 \%$ yield (Scheme 4). The structure of $\mathbf{1 1}$ was 
A. V. Kovtun, S. V. Tokarieva, S. A. Varenichenko et al.

Table 3. The docking binding free energies of the synthesized compounds 3a-c,7-9 against FGFR1

\begin{tabular}{c|c|c|c|c|c|c}
\hline Compound & $3 \mathrm{a}$ & $3 \mathrm{~b}$ & $3 \mathrm{c}$ & 7 & 8 & 9 \\
\hline Binding free energy $(\mathrm{kcal} / \mathrm{mol})$ & -9.2 & -8.9 & -8.8 & -10.1 & - & -9.7 \\
\hline
\end{tabular}

Table 4. The docking binding free energies of the synthesized compounds 3a-c,7-9 against V599E-RAF

\begin{tabular}{c|c|c|c|c|c|c}
\hline Compound & $3 \mathrm{a}$ & $3 \mathrm{~b}$ & $3 \mathrm{c}$ & 7 & 8 & 9 \\
\hline Binding free energy $(\mathrm{kcal} / \mathrm{mol})$ & -9.9 & -9.2 & -9.9 & -10.2 & -10.1 & -9.4 \\
\hline
\end{tabular}

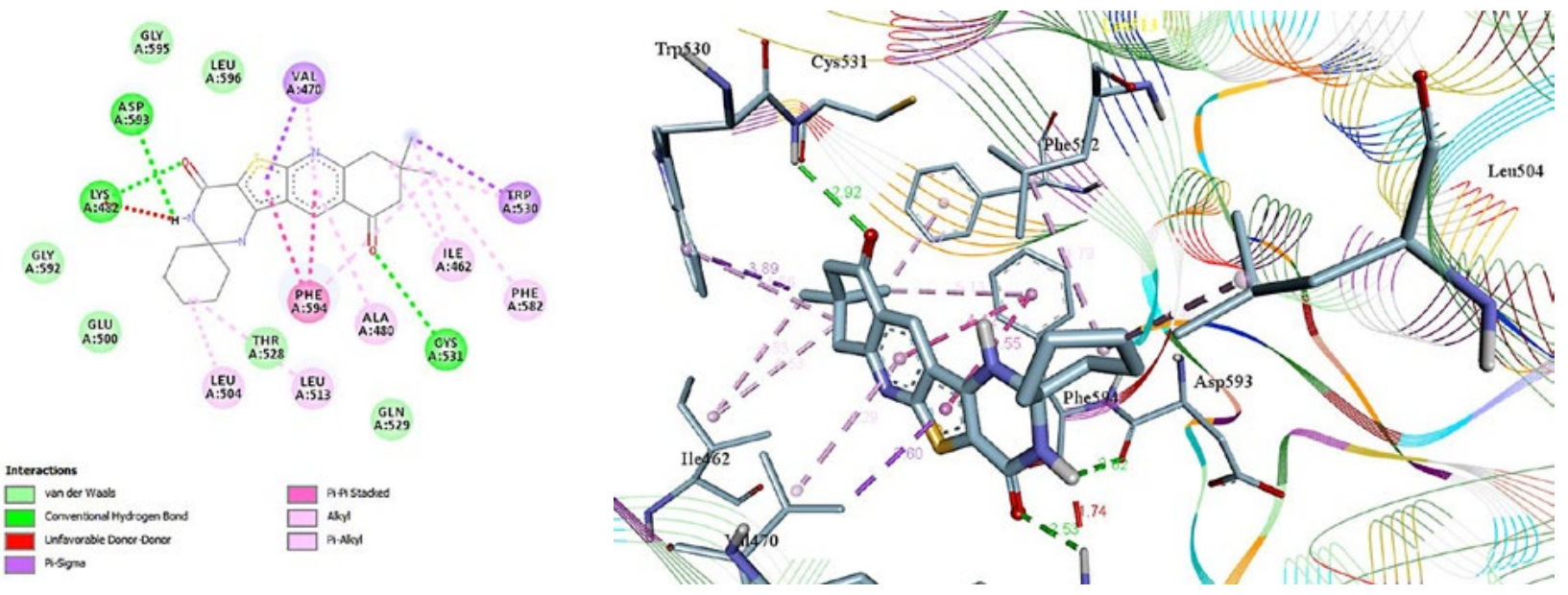

Fig. 3. Binding model of compound $\mathbf{8}$ for the best docked pose in the ATP-binding site of receptor V599EB-Raf (model of the complex obtained by molecular docking, hydrogen bonds are shown in green dashed lines).
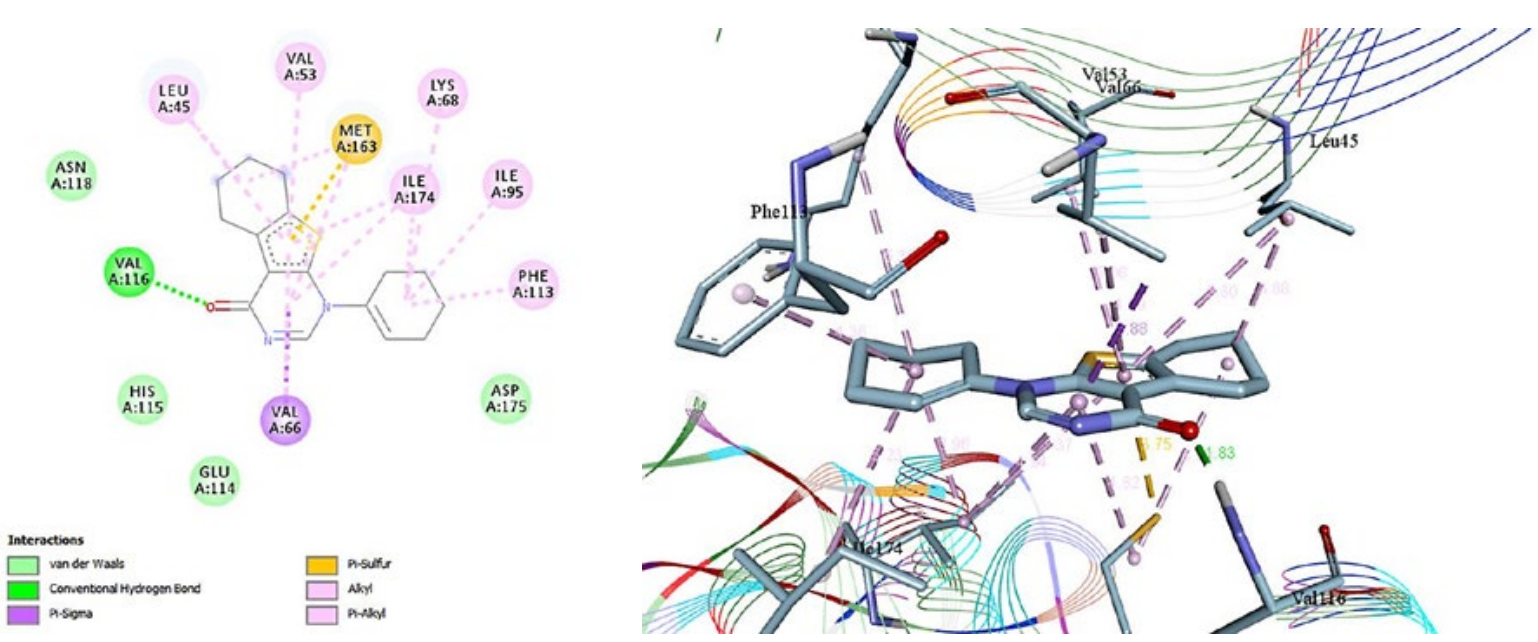

Fig. 4. Binding model of compound 10 for the best docked pose in the ATP-binding site of receptor CK2 (model of the complex obtained by molecular docking, hydrogen bonds are shown in green dashed lines). 
Spirocyclic thienopyrimidines: synthesis, new rearrangement under Vilsmeier conditions and in silico prediction of anticancer activity

Table 5. The docking binding free energies of the synthesized compounds 10-12 against the selected kinases.

\begin{tabular}{|c|c|c|c|c|c|c|c|c|}
\hline \multirow[b]{2}{*}{ № } & \multicolumn{2}{|c|}{ EGFR } & \multicolumn{2}{|c|}{ CK2 } & \multicolumn{2}{|c|}{ FGFR1 } & \multicolumn{2}{|c|}{ B-raf } \\
\hline & $\begin{array}{c}\text { Affinity } \\
(\mathrm{kcal} / \mathrm{mol})\end{array}$ & H-bond & $\begin{array}{c}\text { Affinity } \\
\text { (kcal/mol) }\end{array}$ & H-bond & $\begin{array}{c}\text { Affinity } \\
\text { (kcal/mol) }\end{array}$ & H-bond & $\begin{array}{c}\text { Affinity } \\
\text { (kcal/mol) }\end{array}$ & H-bond \\
\hline 10 & -9.2 & & -10.4 & $\begin{array}{c}\text { Val116 } \\
(1.83 \AA) \\
\end{array}$ & -9.6 & & -9.5 & - \\
\hline 11 & -9.8 & $\begin{array}{c}\text { Lys } 721 \\
\left(2.49 \mathrm{~A}^{\circ}\right)\end{array}$ & -10.3 & - & -10.3 & - & -10.5 & - \\
\hline 12 & -8.9 & $\begin{array}{c}\text { Thr830 } \\
\left(2.73 \mathrm{~A}^{\circ}\right) . \\
\text { Asp831 } \\
\left(2.29 \mathrm{~A}^{\circ}\right)\end{array}$ & -8.8 & - & -8.8 & $\begin{array}{c}\text { Ala564 } \\
(2.68 \text { and } \\
2.79 \AA)\end{array}$ & -9.0 & $\begin{array}{l}\text { Cys531 } \\
(2.01 \mathrm{i} \\
2.80 \AA)\end{array}$ \\
\hline
\end{tabular}

confirmed by NMR studies and mass spectrometry data.

Despite a considerable number of reviews and books covering the chemistry of thienopyrimidines [15-24], there is lack of information on the reactions of spiro-condensed thieno[2,3-d]pyrimidines with $\mathrm{POCl}_{3}$. We found that the treatment of thienopyrimidine $3 \mathbf{a}$ with an excess of $\mathrm{POCl}_{3}$ in boiling $\mathrm{PhMe}$ resulted in the formation of the thieno[2,3- $b]$ quinoline 12 (Scheme 5).

The results of molecular docking studies of compounds 10-12 are presented in the Table 5. Thienopyrimidine $\mathbf{1 0}$ was found to form a hydrogen bond with the amino acid residue Val66 (1.83 $\AA$, Fig. 4) showin the best result with a binding energy of $-10.4 \mathrm{kcal} / \mathrm{mol}$ and therefore might be considered as perspective inhibitor of CK2 kinase. However, we have to admit that the rearrangement products often do not form hydrogen bonds with kinase amino acid residues while revealing moderate binding energies. The absence of binding with H-bonds does not allow us to consider the rearranged products as perspective targets for further screening.

\section{Conclusions}

New spiro-fused thieno[2,3-d]pyrimidines were prepared starting from easily available Gewald's thiophenes and thieno[2,3-b]pyridines. We found that upon the treatment with VilsmeierHaack reagent, the spiro-fused thieno[2,3-d] pyrimidines undergo rearrangement into new thienopyrimidines and -quinolines.

The inhibition activities of novel compounds as potential inhibitors of EGFR, CK2, FGFR1 and B-raf kinases have been examined. Spiro-fused thieno[2,3-d]pyrimidines were recognized as perspective targets for futher screening. According to the docking studies, in most cases the rearranged products do not tend to form any hydrogen bonds with kinase amino acid residues, but showed moderate binding energies. The lack of hydrogen bonding allowed us to consider the products of Vilsmeier-type rearrangement as unsuitable for further studies as kinase inhibitors.

\section{Acknowledgements}

The authors are grateful to the grant for Young Scientists of Dnepropetrovsk region 2018. VVD is grateful for financial support by the 
Russian Ministry of Education and Science (Project No. 0795-2020-0010), RFBR and Government of Krasnodar region according to the research project No. 19-43-230007.

\section{REFERENCES}

1. Lin L, Yan L, Liu Y, Yuan F, Li H. Incidence and death in 29 cancer groups in 2017 and trend analysis from 1990 to 2017 from the Global Burden of Disease Study. J Hematol Oncol. 2019; 12(1):374-89.

2. Bonomi P. Erlotinib: a new therapeutic approach for non-small cell lung cancer. Expert Opin Investig Drugs. 2003; 12(8):1395-401.

3. Vansteenkiste J. Gefitinib (Iressa): a novel treatment for non-small cell lung cancer. Expert Rev Anticancer Ther. 2004; 4(1):5-17.

4. Dominguez I, Sonenshein GE, Seldin DC. Protein kinase CK2 in health and disease: CK2 and its rolein Wnt and NF-kappab signaling: Linking development and cancer. Cell Mol Life Sci. 2009; 66(0):1850-7.

5. The AACR Project GENIE Consortium. AACR Project GENIE: powering precision medicine through an international consortium. Cancer Discov. 2017;7(8):818-31

6. Davies H, Bignell GR, Cox C, Stephens P, Edkins S, Clegg S, Teague J, Woffendin H, Garnett MJ, Bottomley W, Davis N. at all . Mutations of the BRAF gene in human cancer. Nature. 2002; 417(6892): 949-54.

7. Riesco-Eizaguirre G, Gutiérrez-Martínez P, GarcíaCabezas MA, Nistal M, Santisteban P. The oncogene BRAF V600E is associated with a high risk of recurrence and less differentiated papillary thyroid carcinoma due to the impairment of $\mathrm{Na}^{+} / \mathrm{I}-$ targeting to the membrane. Endocr Relat Cancer. 2006;13(1):257-69/

8. Pedretti A, Villa L, Vistoli G. VEGA - An open platform to develop chemobioinformatics applications, using plugin architecture and script programming. J.C.A.M.D. 2004; 18: 167-73.

9. Morris GM, Huey R, Lindstrom $W$, Sanner MF, Belew RK, Goodsell DS, Olson AJ. AutoDock4 and
AutoDockTools4: Automated docking with selective receptor flexibility. J. Comput Chem. 2009; 30 (16): 2785-91.

10. Gewald K, Schinke E, Böttcher H. Heterocyclen aus $\mathrm{CH}$-aciden nitrilen, VIII. 2-amino-thiophene aus methylenaktiven nitrilen, carbonylverbindungen und Schwefel. Chem Ber. 1966; 99:94-100.

11. Kamal El, Dean AM, Shaker R, Abo El, Hassan AA, Abdel Latif FF. Synthesis of some thienotetrahydroquinoline derivatives. J Chin Chem Soc. 2004; 51(2):335-45.

12. Dotsenko VV, Krivokolysko SG, Chernega AN, Litvinov VP. Anilinomethylidene derivatives of cyclic 1,3-dicarbonyl compounds in the synthesis of new sulfur-containing pyridines and quinolines. Russ Chem Bull. 2002; 51(8):1556-61.

13. Shvedov VI, Sycheva TP, Sakovich TV. Research on thienopyridines and pyridothienopyrimidines. 1 . Synthesis of some substituted 3-aminothieno[2,3-b] pyridines. Chem Heterocycl Compds. 1979; 15(10): 1070-74.

14. Seck P, Thomae D, Kirsch G. Synthesis of Substituted Amino-Cycloalkyl[b]thieno [3,2-e]Pyridines. J. Heterocyclic Chem., 2008;45:853-7.

15. Ibrahim YA., Elwahy AHM., Kadry AM. Thienopyrimidines: synthesis, reactions, and biological activity. Adv. Heterocycl. Chem. 1996; 65:235-81.

16. Varvounis $G$, Giannopoulos T. Synthesis, chemistry, and biological properties of thienopyrimidines. $A d v$. Heterocycl. Chem. 1996; 66:193-283.

17. Litvinov VP. Thienopyrimidines: synthesis, properties, and biological activity. Russ Chem Bull. 2004; 53(3):487-516.

18. Litvinov VP. The chemistry of thienopyrimidines Adv. Heterocycl. Chem. 2006; 92:83-143.

19. Noravyan AS, Paronikyan EG, Sirakanyan SN, Hakobyan ShF. [Synthesis and conversion of condensed thieno[2,3- $d]$ - and thieno[3,2- $d]$ pyrimidines]. Chem J Arm. 2012; 65(4):447-73.

20. Aly AA, Ishak EA, Ramadan M, Germoush MO, El, Emary TI, Al, Muaikel NS. Recent Report on Thieno[2,3-d]pyrimidines. Their Preparation Including Microwave and Their Utilities in Fused Heterocycles Synthesis. J Heterocycl Chem 2013; 50(3):451-72. 
21. Bozorov K, Zhao JY, Elmuradov B, Pataer A, Aisa HA. Recent developments regarding the use of thieno[2,3- $d]$ pyrimidin-4-one derivatives in medicinal chemistry, with a focus on their synthesis and anticancer properties. Eur J Med Chem. 2015; 102:552-73.

22. Wilding $B$, Klempier $N$. Newest developments in the preparation of thieno[2,3-d]pyrimidines. Org Prep Proced Int. 2017; 49(3);183-215.

23. Ali EMH, Abdel-Maksoud MS, Oh CH. Thieno[2,3d]pyrimidine as a promising scaffold in medicinal chemistry: Recent advances. Bioorg Med Chem. 2019; 27(7):1159-94.

24. Khripak SM, Slivla MV, Lendel VG. Synthesis and reactions of thieno[2,3-d]pyrimidines. Uzhgorod: "Patent". 2009; 132 p.

25. Vlasov SV, Zhuravel'IO, Chernykh VP. Anticancer activity study of 6-hetarylthieno[2,3- $d]$ pyrimidine derivatives. Ukrainian biopharmaceutical journal. 2015; 4(39):46-51.

26. Gunda SR, Lingala $S$, Allenki $V$. Synthesis and anticancer activity of some novel 3-[(2-substituted6,7,8,9-tetrahydro-5Hcyclohepta[b]thieno[2,3-d] pyrimidin-4-yl)amino]propan-1-ol derivatives. Eur $J$ Pharm Med Res. 2017; 4(6):481-84.

27. Amawi H, Karthikeyan C, Pathak R, Hussein N, Christman R, Robey R, Ashby CR, Trivedi P, Malhotra A, Tiwari AK. Thienopyrimidine derivatives exert their anticancer efficacy via apoptosis induction, oxidative stress and mitotic catastrophe. Eur J Med Chem. 2017; 138:1053-65.

28. Elrazaz EZ, Serya RA, Ismail NS, El Ella DAA, Abouzid KA. Thieno[2,3-d]pyrimidine based derivatives as kinase inhibitors and anticancer agents. Future J Pharm Sci. 2015; 1(2):33-41.

29. Ghith A, Ismail NS, Youssef K, Abouzid KA. Medicinal attributes of thienopyrimidine based scaffold targeting tyrosine kinases and their potential anticancer activities. Arch Pharm. 2017; 350(11): 1700242.

30. Mghwary AES, Gedawy EM, Kamal AM, AbuelMaaty $S M$. Novel thienopyrimidine derivatives as dual EGFR and VEGFR-2 inhibitors: design, synthesis, anticancer activity and effect on cell cycle profile. J Enzyme Inhib Med Chem. 2019; 34(1): $838-52$.
31. Kolomieitsev DO, Varenichenko SA, Astakhina VO, Markov VI, Kovalenko SI, Kharchenko OV. The direction of heterocyclization of 4-hydrazino5,6,7,8-tetrahydro[1]benzotieno[2,3- $d$ ]pyrimidine in reaction with dicarboxylic acid anhydride. Voprosy khimii $i$ khimicheskoi tekhnologii. 2016; 2(106):32-6.

32. Kolomieitsev DO, Markov VI, Varenichenko SA, Astakhina VO, Kovalenko SI, Kharchenko OV, Mazepa $A V$. Dimroth rearrangement in the synthesis of substituted cyclopenta and cyclohexa[4,5]thieno[2',3': 4,5]pyrimido[1,6-b][1,2,4]triazines. Chem Heterocycl Compds. 2016; 52(7):498-502.

33. Dotsenko VV, Krivokolysko SG, Litvinov VP. The Mannich reaction in the synthesis of $\mathrm{N}, \mathrm{S}$-containing heterocycles. 9. A new approach to thieno[2,3-d] pyrimidines. Russ Chem Bull. 2009; 58(7):1524-5.

34. Kolomieitsev DO, Markov VI, Astakhina VO, Kovalenko SI, Varenichenko SA, Kharchenko OV. The synthesis, reactivity and the antimicrobial activity of substituted thieno[2,3-d]pyrimidine-4(3H)thio(seleno)nes. Journal of Organic and Pharmaceutical Chemistry. 2015; 13(4):32-8.

35. Paronikyan EG, Noravyan AS, Vartanyan SA. Synthesis, transformations, and pharmacological properties of thienopyridines. Pharm Chem J. 1987; 21(5):309-17.

36. Bakhite EAG. Recent trends in the chemistry of thienopyridines. Phosphorus Sulfur Silicon Relat Elem. 2003; 178(5):929-92.

37. Litvinov VP, Dotsenko VV, Krivokolysko SG. The chemistry of thienopyridines. Adv Heterocycl Chem. 2007; 93:117-78.

38. Litvinov VP, Dotsenko VV, Krivokolysko SG. The chemistry of thienopyridines and related systems. Moscow: "Nauka". 2006; 407 p.

39. Eurtivong C, Semenov V, Semenova M, Konyushkin L, Atamanenko O, Reynisson J, Kiselyov A. 3-Aminothieno[2,3-b]pyridines as microtubuledestabilising agents: Molecular modelling and biological evaluation in the sea urchin embryo and human cancer cells. Bioorg Med Chem. 2017; 25(2):658-64.

40. Abdelaziz ME, El-Miligy MM, Fahmy SM, Mahran MA, Hazzaa AA. Design, synthesis and docking 
study of pyridine and thieno[2,3-b]pyridine derivatives as anticancer PIM-1 kinase inhibitors. Bioorg Chem. 2018; 80:674-92.

41. Feng L, Reynisdóttir I, Reynisson J. The effect of PLC- $\gamma 2$ inhibitors on the growth of human tumour cells. Eur J Med Chem. 2012; 54:463-9.

42. Arabshahi HJ., Leung E, Barker D, Reynisson J. The development of thieno[2,3-b]pyridine analogues as anticancer agents applying in silico methods. MedChem Comm. 2014; 5(2):186-91.

43. Morris GM, Huey R, Lindstrom W, Sanner MF, Belew RK, Goodsell DS, Olson AJ. Autodock4 and AutoDockTools4: automated docking with selective receptor flexibility. J Comput Chem. 2009; 30(16):2785-91.

44. Trott $O$, Olson $A J$. AutoDock Vina: Improving the speed and accuracy of docking with a new scoring function, efficient optimization, and multithreading. J Comput Chem. 2010; 31(2):455-61.

45. Park JH, Liu Y, Lemmon MA, Radhakrishnan R. Erlotinib binds both inactive and active conformations of the EGFR tyrosine kinase domain. Biochem J. 2012; 448:417.

46. Battistutta R, De Moliner E, Sarno S, Zanotti G, Pinna LA. Structural features underlying selective inhibition of protein kinase CK2 by ATP site-directed tetrabromo-2-benzotriazole. Protein Sci. 2001; 10(11):2200-6.

47. Li N, Batt D, Warmuth M. B-Raf kinase inhibitors for cancer treatment. Curr Opin Investig Drugs. 2007; 8:452-6.

48. Markov VI, Farat OK, Varenichenko SA, Velikaya EV. Rearrangement of 5',6',7',8'-tetrahydro1 ' $H$-spiro(cyclohexane-1,2'-quinazolin)-4'(3' $H$ )one during Vilsmeier reaction. Mendeleev Commun. 2012;22:101-2.

49. Farat OK, Markov VI, Varenichenko SA, Dotsenko $V V$, Mazepa $A V$. The Vilsmeier-Haack formylation of 2,3-dihydro-4H-1,3-benzoxazin-4-ones and isomeric 1,2-dihydro-4H-3,1-benzoxazin-4-ones: an effective approach to functionalized $2 \mathrm{H}-/ 4 \mathrm{H}-$ Chromenes and Tetrahydroacridines. Tetrahedron. 2015; 71:5554-61.

50. Farat OK, Ananyev IV, Varenichenko SA, Zaliznaya EV, Markov VI. A facile approach for the synthesis of novel xanthene derivatives with Vilsmeier-Haack reagent. Chem Heterocycl Compds. 2019; 55(1):38-46

51. Farat OK, Varenichenko SA, Zaliznaya EV, Markov VI. Rearrangement of substituted 1,3-benzoxazines into xanthene-type compounds. Украӥнський хімічний журнал. 2020; 86(2):111-22.

\section{Спіроциклічні тіснопіримідини: синтез, нове перегрупування в умовах реакції Вільсмаєйра та in silico прогнозування протиракової активності}

А. В. Ковтун, С. В. Токарєва, С. А. Варениченко, О. К. Фарат, О. В. Мазепа, В. В. Доценко, В. I. Марков

Мета. Пошук нових дієвих протипухлинних молекул серед легко доступних спіроконденсованих тієно[2,3-d] піримідинів. Методи. Органічний синтез, спектральні методи та молекулярний докінг. Результати. Було синтезовано спірогетероцикли конденсацією амінотіофенів з циклічними кетонами за реакцією Гевальда. Наступні модельні сполуки отримано конденсацією 3-аміно[2,3-b]піридин-2-карбоксамідів з циклогексаноном в умовах кислотного каталізу. Результати докінгу проти кінази EGFR ${ }^{\mathrm{WT}}$ показали, що синтезовані сполуки мають гарні енергії зв'язування у діапазоні від -8.4 до -10.2 ккал/моль. Серед досліджених сполук у якості інгібіторів протеїн кінази СК2 7',8', 9', 10'-тетрагідро-1' $H$-спіро[циклогексан-1,2'-піримідо[4',5':4,5] тієно[2,3-b]хінолин]-4'(3' $H$ )-он показав найкращу енергію зв'язування за наявності водневого зв'язку з амінокислотним залишком Val66. Також дана сполука показала кращі результати як потенціальний інгібітор B-Raf кінази. Висновки. Синтезовано нові спіроконденсовані тієно[2,3-d]піримідини. Досліджено інгібуючу активність нових сполук у якості потенційних інгібіторів кіназ EGFR, CK2, FGFR1 та B-raf. Показано, що спіроконденсовані тієно[2,3-d]піримідини перегруповуються у похідні тієно[2,3-d(b)]піримідин(хінолину) під дією реагенту Вільсмайєра-Хаака. Продукти перегрупування у більшості не утворюють водневих зв'язків з амінокислотними залишками та показують помірні енергії зв'язування. Відсутність водневих зв'язків з амінокислотними залишками продуктів пере- 
групування не дозволяє рекомендувати їх для подальших досліджень на відміну від спіроконденсованих тієно[2,3-d]піримідинів.

Кл юч о в i с л о в а: тієно[2,3-d]піримідини, тієно[2,3-b]піридини, спірогетероцикли, реакції Вільсмайєра-Хаака, молекулярний докінг, протиракова активність, інгібітори кіназ.

\section{Спироциклические тиенопиримидины: синтез, новая перегруппировка в условиях реакции Вильсмайера и in silico прогнозирование протираковой активности}
А. В. Ковтун, С. В. Токарева, С. А. Варениченко, О. К. Фарат, А. В. Мазепа, В. В. Доценко, В. И. Марков

Цель. Поиск новых действенных противоопухолевых молекул среди легко доступных спироконденсированных тиено[2,3-d]пиримидинов. Методы. Органический синтез, спектральные методы и молекулярний докинг. Результаты. Были синтезированы спирогетероциклы конденсацией аминотиофенов с циклическими кетонами по реакции Гевальда. Следующие модельне соединения получены конденсацией 3-амино[2,3-b]пиридин-2-карбоксамидов с циклогексаноном в условиях кислотного катализа. Результаты докинга против киназы EGFR ${ }^{\mathrm{WT}}$ показали, что синтезированные соединения имеют хорошие энергии связывания в диапазоне от -8.4 до -10.2 ккал/моль. Среди исследованных соединений в качестве ингибиторов протеїн киназы СК2 7',8',9',10'-тетрагидро-1' $H$-спиро[циклогексан-1,2'-пиримидо[4',5':4,5]тиено[2,3-b]хинолин]-4'(3' $H$ )-он показал лучшую энергию связывания при наличии водородной связи с амикислотным остатком Val66. Также данное соединение показало лучшее результаты как потенциальный ингибитор B-Raf киназы. Выводы. Синтезированы новые спироконденсированные тиено[2,3-d]пиримидины. Изучена ингибирующая активность новых соединений в качестве потенциальных ингибиторов киназ EGFR, CK2, FGFR1 и B-raf. Показано, что спироконденсированные тиено[2,3-d]пиримидины перегруппировываются в производные тиено[2,3-d(b)]пиримидин(хинолина) под. действием реагента Вильсмайера-Хаака. Продукты перегруппировки в большинстве не образуют водородных связей с аминокислотными остатками и показывают умеренные энергии связывания. Отсутствие водородных связей продуктов перегруппировки не позволяет рекомендовать их для дальнейших исследований в отличие от спироконденсированных тиено[2,3-d] пиримидинов.

Кл ю ч е в ы е с л ов а: тиено[2,3-d]пиримидины, тиено[2,3-b]пиридины, спирогетероциклы, реакция Вильсмайера-Хаака, молекулярный докинг, противораковая активность, ингибиторы киназ.

Received 20.04.2020 